has lived many years in Siam, assures me that he has travelled round the Gunong Kendrong group at the head of the Perak, and that it is quite detached from any other hills.

Perak River.-The whole of these groups are sufficiently connected to prevent any drainage from the central range flowing directly to the west coast of the peninsula. Thus the Perak River, which has its sources in the Keddah and Patani Mountains flows to the southward for over I80 miles. In its course it is joined by two important rivers from the eastward, namely, the Plus and Kinta.

Plus River.-The Plus River has its sources in the high mountain groups east of Mount Inas, and in the main range. It flows round the southern end of a group called by some the Bukit Panjang Range, and then joins the Perak.

Kinta Ranges.-South of this junction is a group of mountains called by some the Kinta Ranges. This group is about twenty-five miles long. It is perfectly detached from all the others, having a generally north and south direction, but sending off spurs from its west side a little to the west of south. The group is entirely granitic, but on its lower slopes has thick deposits of limestone belonging to the formation already referred to, above and below which tin is worked. For about twentyfive miles this range separates the valley of the Perak River from that of the Kinta, which flows on its eastern side. The highest peaks rise to about 3750 feet above the sea, and give rise to small streams which all flow into the Perak. There is a remarkable uniformity in three or four of the highest summits, which are about the centre of the chain, Mounts Merah (red), Prungin, \&c. They are all within a few feet of the same height. From thesc mountains the range falls away gradually to the south, and sends off two considcrable spurs to the south-west. Where it ceases the River Kinta joins the Perak.

Kinta Valley. - The valley of the Kinta River is about as wide as that of the Perak. The river flows, like the Perak, on the eastern side of the valley. The castern tributaries are many and important. On the sides limestone granite and schistose slates crop out. To the castward there are many detached hills of limestone fronting the main central chain. They form very characteristic features in the landscape, from their precipitous outline, and the brilliantly coloured faces of blue, green, and bright red rock. They are also distinguished by a different vegetation.

Perak Valley.-The valley of the Perak River is bounded by the groups of mountains already described on the west; on the east by the Kinta Range, and north of the Plus by the Bukit Panjang Range. The river flows on the eastern side of the valley; this is owing to the many spurs and outliers on the eastern sides of Mounts Bubu and the Ijau Ranges. It seems as if there had been much less denudation on the eastern than on the western sides of the range. This may be owing to the prevailing rains falling more abundantly on the western than on the eastern sides of the mountains.

As a consequence of this the tin workings appear to be, with little exception, on the western sides of the ranges, where the waste and wash has probably been greater.

Batu Kurau.-Between Mount Bubu Range and Mount Ijau Range and the sea there are no hills except small outliers, mostly of Palæozoic clay, which have eviclently belonged to the ranges. But north of the Larut River there is an isolated limestonc mountain near the Kurau River. This is called Batu (stone or rock in Malay) Kurau. It is very similar to Mount Poudok in the Gapis Pass. It is quite unconnected with the main range, and rises out of the plain between the spurs which form the valley of the Kurau River. There is also a small detached range dividing the valley of the Krian River from that of the Kurau.

Main Range.-Of the main range I know but very little from personal observation, having only visited it at Goping, and at the limestone hills, where the tin is worked on the Diepang River. But I have travelled along the most of the Kinta Valley skirting the base of the range either on foot or in boats. I have also traced the valley of the Kampar River. The geology is like the rest of the country, mainly granite, slates, and limestone, with traces of basaltic rocks. The general structure of the range can best be judged from some of the mountains to the westward. It forms a most imposing boundary to the whole of the western horizon. In the north, about the sources of the Plus River, there is a mountain of rounded outline, probably over 6000 feet high. The range there declines a little, with a somewhat serrated outline, but generally over 3000 feet. At a point corresponding with the latitude of about the centre of the Kinta Range, or opposite the Gapis Pass, the chain increases in elevation to perhaps over 5000 feet, and in the distance is seen a peak which must be over 8000 feet high. I know no name for this hill, but it is the most distant mountain usually seen. South and west of this the chain rises into a grand cluster of peaks, the highest of which is over 7000 feet. This is Gunong Robinson. It looks higher than the Sugar-Loaf $H$ ill as seen from Gunong Bubu, but then it is much nearer. From Gunong Robinson the range declines to the southward, but is still a bold series of picturesque peaks, many of which must be over 6000 feet. It has been asserted by more than one observer that to the south of the point where the range is lost sight of from Arung Pura, there is a high mountain occasionally visible higher than any other in the main range, and probably over 12,000 feet. This I have not seen, but I am convinced that there are many things yet to be learned about the most elevated portions of this mountain chain. Seen from any point of view, it forms a magnificent mountain prospect. Its mysterious unexplored recesscs are rendered more gloomy than any scene in the world from the dense forest and the masses of vapour and cloud with which they are always clothed. A few savage Sakies are the only inhabitants. I may add that perhaps in no country in the world is exploration rendered so difficult fiom the extraordinary thickness of the jungle and the steepness of the mountain ridges which unceasingly cross the traveller's path.
Penang, September 8
J. E. TENISON-WoODS

\section{A NEW APPLICATION OF SCIENCE}

\section{$\mathrm{D}^{\mathrm{K}}$}

. FERRIER'S researches on the brain, to which wo have often drawn attention in these columns, have lately receiveci an application of the most startling character. What this application is cannot be better stated now than in the accompanying letter, signed "F.R.S.," which appeared in Tuesday's Times. We shall return to this subject next week.

"While the Bishop of Oxford and Prof. Ruskin were, on somewhat intangible grounds, denouncing vivisection at Oxford last Tuesday afternoon, there sat at onc of the windows of the Hospital for Epilepsy and Paralysis, in Regent's Park, in an invalid chair, propped up with pillows, pale and careworn, but with a hopeful smile on his face, a man who could have spoken a really pertinent word upon the subject, and told the right rev. prelate and the great art critic that he owed his life, and his wife and children their rescuc from bereavement and penury, to some of these experiments on living animals which they so roundly condemned. The case of this man has been watched with intense interest by the medical profession, for it is of an unique description, and inaugurates a new era in cerebral surgery; and now that it has been brought to a successful issue, it seems desirable that a brief outline of it should be placed before the general public, because it illustrates vividly the benefits that physiological explorations may confer on mankind, shows how speedily useful fruit may be gathered from researches undertaken in the pursuit of knowledge and with no immediate practical aim, and reveals 
impressively the precision and veracity of modern medical science.

"This case, then-this impressive and illustrative case-is that of a man who, when admitted to the Hospital for Epilepsy and Paralysis, presented a group of symptoms which pointed to tumour of the brain-a distressing and hitherto necessarily fatal malady, for the diagnosis or recognition of which we are indebted to bed-side experience and post-mortem examination. But while clinical and pathological observations have supplied us with knowledge which enables us to detect the existence of tumours of the brain, they have not afforded us any clue to the situation of these morbid growths in the brain mass, and it was not until Prof. Ferrier had, by his experiments on animals, dernonstrated the localisation of sensory and motor functions in the cerebral hemispheres that the position of any diseased process by which they might be invaded could be definitely determined. By the light of these experiments it is now possible in many instances to map out the seat of certain pathological changes in these hemispheres with as much nicety and certainty as if the skull and its coverings and linings had become transparent, so that the surface of the brain was exposed to direct inspection. And thus in the case to which I am referring, Dr. Hughes Bennett, under whose care the patient was, guided by Ferrier's experiments, skilfully interpreted the palsies and convulsive movements which the man exhibited, and deduced from them that a small tumour was lodged at one particular point in his " dome of thought," and was silently and relentlessly eating its way into surrounding textures. Not more surely do the fidgetings of the electric needle intimate their origin and convey a meaning to the telegraph clerk than did the twitchings of this man's muscles announce to Dr. Hughes Bennett that a tumour of limited dimensions was ensconced at a particular point of a particular fold or convolution of the brain -the ascending frontal convolution on the right side.

"Very brilliant diagnosis this, it may be remarked, and nothing more. A conclusion has been arrived at which, should it prove correct, will gratify professional pride; but as it cannot be confirmed or refuted until the poor patient is no longer interested in the matter, and cannot be made the basis of any active interference, no great advance has been made after all, and vivisection has yielded only some barren knowledge. Until quite recently, criticism of this kind would have been justifiable in a sense, but now it is happily no longer possible, for another series of experiments on living animals, undertaken by Profs. Ferrier and Yeo, have proved that through our power of localising brain lesions we may open a gateway for their removal or relief. The old notion that the brain is an inviolable organ with noli me tangere for its motto-a mysterious and secluded oracle of God that simply falls down and dies when its fane is desecrated by intrusion- has been dissipated by these experiments; and we now know that under punctilious antiseptic precautions the brain, in the lower animals at any rate, may be submitted to various operative procedures without risk to life or fear of permanent injury. Emboldened by this knowledge, Dr. Hughes Bennett devised a way of helping his patient whose disease he had diagnosed with such remarkable exactitude, and gave him one chance, if he nad the courage to embrace it, of saving his life and recovering his health.

"The patient had the position in which he stood faithfully explained to him. He was told that he laboured under a malady which medicines were powerless to touch, and that if left unassisted he must die in a few months at latest, after prolonged sufferings similar to those which had already brought him to the verge of exhaustion, and which could be only partially alleviated by drugs; but that one outlet of escape, narrow and dangerous, but still an outlet, was open to him in an operation of a formidable nature and never before performed on a human being, under which he might, perhaps, sink and die, but from which he might, perhaps, obtain complete relief. The man, who had faith in his doctor, and no fine-spun scruples about availing himself of the results of vivisectional discoveries, eagerly chose the operation. On the $25^{\text {th }}$ ult. accordingly, Mr. Godlee, surgeon to University College Hospital, in the midst of an earnest and anxious band of medical men, made an opening in the scalp, skull, and brain membranes of this man at the point where Dr. IIughes Bennett had placed his divining finger, the point corresponding with the convolution where he declared the peccant body to be, and where sure enough it was discovered. In the substance of the brain, exactly where Dr. Hughes Bennett had predicted, a tumour, the size of a walnut was found-a tumour which Mr.
Godlee removed without difficulty. The man is now convalescent, having never had a bad symptom, and full of gratitude for the relief afforded him. He has been snatched from the grave and from much suffering, and there is a good prospect that he will be restored to a life of comfort and usefulness. In that case he will be a living monument of the value of vivisection. The medical profession will declare with one voice that he owes his life to Ferrier's experiments, without which it would have been impossible to localise his malady or attempt its removal, and that his case opens up new and far-reaching vistas of hopefulness in brain-surgery. Many men and women will henceforth, there is reason to anticipate, be saved from prolonged torture and death by a kind of treatment that has been made practicable by the sacrifice, under anæsthetics, of a few rabbits and monkeys."

\section{NOTES}

The Council of the British Association for the Advancement of Science has requested the following to allow themselves to be nominated as Presidents of Sections for the meeting at Aberdeen, which begins on Wednesday, September 9, 1885 :- Section A (Mathematics, \&c.), Prof. J. C. Adams; Section B (Chemistry), Prof. Armstrong; Section C (Geology), Prof. Judd ; Section D (Biology), Prof. McIntosh; Section E (Geography), General Walker; Section F (Economics), Prof. J. Bryce; Section G (Mechanics), Mr. B. Baker; Section H (Anthropology), Mr. F. Galton.

$W_{F}$ Iearn with pleasure that M. Mascart was on Monday last elected a Member of the Academie des Sciences, Paris.

THE Berkeley Research Fellowship has been given by Owens College, Manchester, to Mr. G. H. Fowler of Keble College, Oxford. An opportunity is thus given to Mr. Fowler of carrying on his work on the anatomy of the Zoantharian corals.

THE immense economical importance of Government botanic gardens, especially in young colonies, is well shown by the last report of the Curator of the Gardens in Brisbane. Omitting the distribution of ornamental trees, shrubs, \&c., to the gardens of public institutions, as well as that of ornamental pot plants, we find that economic plants have been distributed on a very large scale. The demand for these has been unprecedentedly large, and no application is ever refused so far as it can be supplied. About 3000 economic plants were sent out during the year; these consisted chiefly of various kinds of coffee, tea, cocoa (Theobroma cacao), cinchona, and vanilla. Grafted Indian mangoes and plants of the Prazilian nut (Bertholletia excelsa) have been given to likely growers, and the demand for the latter is so great that application has been made to the universal feeder of these insti. tutions, Kew, for more. Besides acting as a collecting and distributing agency, the Brisbane Gardens do what is perhaps of even more value, viz, ascertain by experiment the conditions under which certain foreign plants will grow best in the colony. The most important trials recently have been with regard to cinchona, which, Mr. Pink shows, may by care in its early stages, be successfully cultivated in Queensland. The hop plant has been tried, and appears a success, Io cwt. being the produce per acre the first season, while in England under similar circumstances it is only 4 cwt. Sugar is at present the staple of the colony, but no efforts are spared to discover new kinds elsewhere which may be better adapted to the place. Ioo tons of various kinds of cane, chiefly from Mauritius, were sent to planters during the year. Economic and valuable timbers also receive much attention, and the gardens have now ready for transplanting 20,000 trees of various kinds, including cedars, olives, silky oak, English oak, English ash, poplars, and chestnuts. The recent experiments have conclusively shown that Queensland can introduce among her staple produce-crops such valuable and remunerative products of the soil as coffee, hops, 